\title{
IMPACT OF SOCIAL MEDIA IN ONLINE SHOPPING
}

\author{
C. Arul Jothi and A. Mohmadraj Gaffoor \\ School of Management Studies, Bannari Amman Institute of Technology, India
}

\begin{abstract}
:
Social media has revolutionised the ways of communication and sharing information and interests. The rapid growth of social media and social networking sites, especially, in developing country like India is providing marketer a new avenue to contact customers. The study attempts to assess the impact of usage of social media on purchase decision process. The study finds that the social media is most widely used in information source for entertainment, networking, and information on new brands. Also, the social media reviews and opinions affect the purchase decision process; however, tendency of share their experiences post purchase is surprisingly good.
\end{abstract}

\section{Keywords: \\ Social Media, Online Purchase, Advertisement, Decisions, Factors Influence}

\section{INTRODUCTION}

The growth of e-commerce was driven by rapid technology adoption led by the increasing use of devices such as smart phones and tablets, and access to the internet through broadband, 3G, 4G, etc. increased online consumer base. Furthermore, favoured demographics and a growing internet user base helped to aid this growth. In terms of highlights, the growth shown by home-grown players such as Flipkart and Snapdeal and the huge investor interest around these companies displayed the immense potential of the market. With the entry of e-commerce behemoths such as Amazon and Alibaba, the competition is expected to further intensify. Both these international players come with deep pockets and the patience to drive the Indian e-commerce market [8].

The impact of social media on online purchase is very high. It serves a vital purpose in online marketing by helping companies to establish stronger web presence, generate leads and increase traffic [9]. A well-structured social media strategy is important for improving the development and growth of an ecommerce business. Social media continues to gain popularity owing to its commercial success around the world. A significant percentage of advertising campaigns take place through social media website. Including social media in an effort to advance ecommerce can be highly beneficial. It provides an effective way to attract the interest of the large audiences that uses social media [5-7].

The use of social media has witnessed rapid growth over a time with several people making purchases through it. Many businesses have opted to take advantage of the opportunities presented by social media networks to obtain more customers. Although some business owners may be sceptical about using social media, the reality is that it is a worthwhile inclusion in online marketing campaigns [10].
- Social media sites cater for innovative features such as 'like' buttons and comment sections frequently used to facilitate conversations. Sharing information through social media is important because of the impact it has on the choices that people make when selecting products and services.

- Incorporating Share buttons for social media platforms such as LinkedIn, Facebook and Twitter on your website will allow you to advertise your business and promote interaction. Several social media users make their purchases online after they share items on Pinterest, Facebook and Twitter. This is a clear indication of how vital social media networking is in ecommerce. Consumers around the world will be spending billions of their hard earned money annually through the accessible platforms of social media.

\subsection{POPULAR SOCIAL MEDIA OPTIONS}

- Facebook has been cited as the ideal social media platform for creating brand awareness and engaging with consumers.

- Twitter is suitable for encouraging interaction with customers and the hash tag feature makes it easier to share valuable content.

- YouTube is an excellent choice for businesses that want to use videos to promote their brands and increase their visibility;

- Pinterest is a worthwhile option for you if you need to offer merchandise exclusively and showcase products in advance.

\subsection{VALUE OF SOCIAL MEDIA}

Social media needs to be a part of a company's marketing budget because it gives a powerful way to create a connection with the targeted audience. From Instagram to LinkedIn, there are virtually limitless ways to interact and share information as well as market the products. Social networks enable to connect with new customers and stay in touch with the existence customers. Social media enhances customer service by creating accessibility to customers who have a tendency to seek immediate feedback. It responds in a timely manner to their concerns and inquiries. Consumers rely on social sites to find out about products and services. Optimized profiles and useful information will create a positive first impression for online business.

\subsection{OBJECTIVES}

- To study the consumers profile that purchase products from online;

- To identify the factors influence the customers to purchase products through social media;

- To find the products purchased through online; and

- To analyse the post purchase behaviour of consumers. 


\section{REVIEW OF LITERATURE}

Hoffman and Novak [4] have indicated that interactivity is the key distinguishing feature between marketing communication on the Internet and traditional mass media. Today online consumers have more control and bargaining power than consumers of physical stores because the Internet offers more interactivities between consumers and product/service providers as well as greater availability of information about products and services. Geissler and Zinkhan [3] claimed that the Internet shifted the balance of power in favor of consumers as it became very easy for them to make shopping comparisons and evaluate alternatives without being pressured by salespeople. Online stores reduce transaction costs and have advantage for both consumers and vendors. Armstrong, Armstrong et al. [1] have the study on consumer buying behavior based on purchase intention has been developed in marketing for more than 20 years. One issue remains disputable is whether purchase intention can effectively predict consumer buying behavior. Norazah Suki and Norbayah Suki [14] suggested marketers should propose more on attractive promotion such as advertisements or discounts through the web. Yulihasri et al. [16] studied the usefulness of internet shopping, ease of use, compatibility, privacy, security, normative beliefs, self-efficacy, attitude and student's buying intention. They found that web advertising favorably influences the purchasing of a company's products. Shoppers increasingly want what's called a "seamless omni channel experience", meaning one in which retailers allow them to combine online and brick and mortar browsing, shopping, ordering and returning in whatever combo they would like. Sharma et al [15], assessed the online buying behavior of consumers in India, and found that consumers are feared of unsecured transactions in online payment and majority of online buyers are from 18-25 years. Ioanas and Stoica [2] address the impact of social media on consumer behavior, consumers prefers online buying for convenience and most of the customers are checking the product information before buying the products. Bauboniene and Guleviciute [13] the main factors influencing consumers to shop online are convenience, simplicity and better price. Muda et al. [11] investigated that online purchase behavior of Gen Y in Malaysia and identify the factors drive the behavior. They found that Gen Y in Malaysia buys mostly from online retailers operating via Facebook and Instagram.

\section{RESEARCH METHODOLOGY}

The research design selected for the study is exploratory and descriptive in nature. Exploratory research design is defined as "Investigation into a problem or situation which provides insights to the researcher. The research is meant to provide details where a small amount of information exists. It may use a variety of methods such as trial studies, interviews, group discussions, experiments, or other tactics for the purpose of gaining information, and Descriptive research includes surveys and factfinding enquiries of different kinds. The major purpose of descriptive research is description of the state of affairs as it exists at present.

The questionnaire had the following dimensions:

- Socio and Economic profile of the respondent such as gender and age, education, occupation and income
- The technological, consumers and product/service factors influencing the online purchase.

- Behavior of visiting social media sites, frequency of visits, amount spent and product purchased.

- Various attributes induce social media users are entertainment, networking, information on new brands, and so on.

\subsection{DATA COLLECTION}

Data is collected through primary sources. A well-structured questionnaire prepared to collect data from respondents related Socio and Economic and attributes induce social media users. Data was collected from 70 respondents where 100 respondents were targeted to obtain information, but the filled in responses received through online was 74 and four questionnaires were partly filled. So those four were deleted from survey and used 70 responses to conduct the present study.

\subsection{PRIMARY DATA}

The primary data are those which are collected a fresh and for the first time and thus happen to be original in character. The primary data are collected through survey. This study has collected primary data through questionnaire from various respondents such as students, professors, private sector employees and IT employees.

\subsection{SECONDARY DATA}

Secondary data is the data that have been already collected and readily available from the other sources such as, various publications of Central, State and Local Governments, various publications of foreign governments or International bodies, Technical and trade journals, Books, magazines, and new paper, reports prepared by research scholars, university economists and so on.

\subsection{PERIOD OF STUDY}

The study period of this research exercise is January February 2017.

\subsubsection{Tools for Analysis:}

- Percentage Analysis;

- Cross Tabulation;

- Chi Square Test and

- Mean Score were used to analyse the collected data.

\section{ANALYSIS AND DISCUSSIONS}

\subsection{PERCENTAGE ANALYSIS}

Table.1. Socio Economic Profile of Customers

\begin{tabular}{|c|c|c|c|}
\hline \multicolumn{2}{|c|}{ Particulars } & $\begin{array}{c}\text { No. of } \\
\text { respondents }\end{array}$ & Percentage \\
\hline \multirow{3}{*}{ Age } & $18-22$ & 32 & 46.2 \\
\cline { 2 - 4 } & $23-27$ & 24 & 33.5 \\
\cline { 2 - 4 } & $28-32$ & 14 & 20.3 \\
\hline
\end{tabular}




\begin{tabular}{|c|c|c|c|}
\hline & Total & 70 & 100 \\
\hline \multirow{3}{*}{ Gender } & Male & 42 & 60.0 \\
\hline & Female & 28 & 40.0 \\
\hline & Total & 70 & 100 \\
\hline \multirow{4}{*}{$\begin{array}{c}\text { Education } \\
\text { Qualification }\end{array}$} & Under graduate & 27 & 38.6 \\
\hline & Post graduate & 35 & 50.0 \\
\hline & Professional & 8 & 11.4 \\
\hline & Total & 70 & 100 \\
\hline \multirow{7}{*}{ Occupation } & Assistant professor & 2 & 2.8 \\
\hline & Unemployed & 1 & 1.4 \\
\hline & Private & 27 & 38.5 \\
\hline & Student & 38 & 54.3 \\
\hline & Tutor & 1 & 1.4 \\
\hline & Teacher & 1 & 1.4 \\
\hline & Total & 70 & 100.0 \\
\hline \multirow{6}{*}{ Income level } & Rs.20000-30000 & 38 & 54.3 \\
\hline & Rs.30001-40000 & 14 & 20.0 \\
\hline & Rs.40001-50000 & 5 & 7.1 \\
\hline & Rs.50001-60000 & 1 & 1.4 \\
\hline & >Rs. 60000 & 12 & 17.1 \\
\hline & Total & 70 & 100 \\
\hline \multirow{4}{*}{ Residence } & Rural & 16 & 22.9 \\
\hline & Semi-urban & 26 & 37.1 \\
\hline & Urban & 28 & 40.0 \\
\hline & Total & 70 & 100.0 \\
\hline
\end{tabular}

Source: Primary Data

\subsubsection{Age:}

Out of 70 Respondents, $46.2 \%$ of the respondents are in the age group of $18-22$, followed by $23-27$ (33.5\%), 28-332 (20.3\%). The minimum age of the respondents begin with 18 years and the maximum was 32 years, which shows that irrespective of the age the respondents are involved in online shopping. All of them are having Social Media Account.

\subsubsection{Gender:}

Out of 70 Respondents $60.0 \%$ of the respondents are male and $40.0 \%$ are female who are all buying the products through online shopping.

\subsubsection{Education Qualification:}

Out of 70 respondents, $38.6 \%$ are Under Graduate, $50.0 \%$ are Post Graduate and $11.4 \%$ are Professional Courses like Charted Accountant.

\subsubsection{Occupation:}

Out of 70 respondents, $54.3 \%$ are Students, $38.5 \%$ are Private employees, $2.8 \%$ are Assistant Professors, and the rest Unemployed, Tutor, Teacher are sharing each $1.4 \%$.

\subsubsection{Income Level:}

Out of 70 respondents, $54.3 \%$ are earning Rs.20000-30000 per month, 20\% are earning Rs.30001-40000 per month, $7.1 \%$ are earning Rs.40001-50000 per month, $1.4 \%$ are earning Rs.40001-
50000 per month, and the rest $17.1 \%$ are earning more than Rs.60000 per month.

\subsubsection{Residence:}

Out of 70 respondents, $40 \%$ are from Urban Area, $37.1 \%$ are from Semi-Urban Area, 22.9\% are from Rural Area.

Table.2. Classifications of Respondents Based on Social Media Accounts Holders

\begin{tabular}{|c|c|c|}
\hline Social Media Account & $\begin{array}{c}\text { Number of } \\
\text { respondents }\end{array}$ & Percentage \\
\hline Facebook & 18 & 25.7 \\
\hline LinkedIn & 2 & 2.9 \\
\hline WhatsApp & 1 & 1.4 \\
\hline Facebook, Instagram & 1 & 1.4 \\
\hline Facebook, LinkedIn & 12 & 17.1 \\
\hline Facebook, Pinterest & 1 & 1.4 \\
\hline Facebook, Twitter & 3 & 4.3 \\
\hline Facebook, Vero & 1 & 1.4 \\
\hline Instagram, Pinterest & 1 & 1.4 \\
\hline Facebook, Instagram, Pinterest & 1 & 1.4 \\
\hline Facebook, LinkedIn, Instagram & 2 & 2.9 \\
\hline Facebook, Twitter, Instagram & 3 & 4.3 \\
\hline Facebook, Twitter, LinkedIn & 8 & 11.4 \\
\hline Facebook, Twitter, WhatsApp & 1 & 1.4 \\
\hline Facebook, LinkedIn, Instagram, Hike & 1 & 1.4 \\
\hline $\begin{array}{c}\text { Facebook, Twitter, LinkedIn, } \\
\text { Instagram }\end{array}$ & 9 & 12.9 \\
\hline $\begin{array}{c}\text { Facebook, Twitter, LinkedIn, } \\
\text { Instagram, Pinterest }\end{array}$ & 1 & 1.4 \\
\hline $\begin{array}{c}\text { Facebook, Twitter, LinkedIn, } \\
\text { WhatsApp, Hike }\end{array}$ & 1 & 1.4 \\
\hline Total & 70 & 100 \\
\hline
\end{tabular}

Source: Primary Data

It is evident from the Table. 2 that $30 \%$ are holding a social media accounts in Facebook (25.7\%), LinkedIn (2.9\%) and WhatsApp (1.4\%). 25\% of Respondents were having two social media accounts of which $17 \%$ are having Facebook and LinkedIn, $4 \%$ were having Facebook and Twitter, rest been shared by Facebook and Instagram, Facebook and Vero, Instagram and Pinterest. Similarly $21.4 \%$ are having accounts in three social media of which $11.4 \%$ are in Facebook, Twitter and LinkedIn, 4\% in Facebook, Twitter and Instagram, 3\% in having Facebook, LinkedIn and Instagram, the rest are Facebook, Instagram, Pinterest and Facebook, Twitter, WhatsApp each $1.4 \%$ respectively totally $14.3 \%$. Of respondents are having accounts in 4 Social media of which $12.9 \%$ in Facebook, Twitter, LinkedIn, Instagram, rest $1.4 \%$ in Facebook, LinkedIn, Instagram, Hike. Only3\% having accounts in 5 social media such as Facebook, Twitter, LinkedIn, Instagram, Pinterest and Facebook, Twitter, LinkedIn, WhatsApp, Hike each hold $1.4 \%$ respectively. 
It is proved that, out of 70 respondents, 66 has Facebook account. Hence, it is seen that Facebook is dominating the social media sites than other sites.

Table.3. Classifications of Respondents Based on Frequency of Accessing Social Media Account

\begin{tabular}{|c|c|c|}
\hline $\begin{array}{c}\text { Frequency of } \\
\text { Accessing }\end{array}$ & $\begin{array}{c}\text { Number of } \\
\text { respondents }\end{array}$ & Percentage \\
\hline Every hour & 10 & 14.3 \\
\hline Every Day & 43 & 61.4 \\
\hline Every Week & 9 & 12.9 \\
\hline Fortnightly & 2 & 2.9 \\
\hline Once in a Month & 6 & 8.6 \\
\hline Total & 70 & 100 \\
\hline
\end{tabular}

Source: Primary data

The Table. 3 presents the frequency of accessing social media $\mathrm{a} / \mathrm{c}$ by respondents. Accessing frequency measurement ranges from one hour to once in month.61.4\% of respondents are accessing their social media accounts everyday followed by $14.3 \%$ were accessing every hour in a day which means their working hours in a day. $13 \%$ access every week rest $11 \%$ access once in month and fortnightly 9 and 3\% respectively. Accessing of social media accounts on daily basis is maximum.

Table.4. Classifications of Respondents Based on Purpose of Holding Social Media Account

\begin{tabular}{|c|c|c|}
\hline Purpose & $\begin{array}{c}\text { Number of } \\
\text { respondents }\end{array}$ & Percentage \\
\hline Entertainment & 8 & 11.4 \\
\hline $\begin{array}{c}\text { Entertainment, Keep in touch with } \\
\text { friends }\end{array}$ & 19 & 27.1 \\
\hline Entertainment, To learn information & 24 & 34.3 \\
\hline Keep in touch with friends & 8 & 11.4 \\
\hline $\begin{array}{c}\text { Keep in touch with friends, gives the } \\
\text { news of the things happening in } \\
\text { world }\end{array}$ & 1 & 1.4 \\
\hline To learn information on products & 4 & 5.7 \\
\hline $\begin{array}{c}\text { To learn information on products, } \\
\text { Keep in touch with friends }\end{array}$ & 5 & 7.1 \\
\hline $\begin{array}{c}\text { To share needed info and for sharing } \\
\text { doc }\end{array}$ & 1 & 1.4 \\
\hline Total & 70 & 100 \\
\hline
\end{tabular}

Source: Primary data

The Table. 4 represents the purpose of holding social media accounts out of 70 respondents $34 \%$ are using Social Media for Entertainment, To learn info, followed by $27 \%$ were using Social Media for Entertainment, Keep in touch with friends, $11 \%$ are using for Entertainment and another $11 \%$ for keep in touch with the friends, $7 \%$ to know the info about products and keep in touch with friends, $5 \%$ to learn info on products and rest each $1.4 \%$ are using to be in touch with friends, gives the news of the things happening in world and to know info about products and to share documents with friends.
It is provided from the respondent's responses that the major purpose of using the social media is entertainments and to know information about new products in the market.

Table.5. Classifications of Respondents Based on Time Spent on Social Media a Day

\begin{tabular}{|c|c|c|}
\hline $\begin{array}{c}\text { Time Spent } \\
\text { (in hours.) }\end{array}$ & $\begin{array}{c}\text { Number of } \\
\text { respondents }\end{array}$ & Percentage \\
\hline $1-3$ & 58 & 82.8 \\
\hline $4-6$ & 10 & 14.3 \\
\hline$>6$ & 2 & 2.9 \\
\hline Total & 70 & 100 \\
\hline
\end{tabular}

Source: Primary data

The Table.5 represents the time spent on social media by respondents a day. Times spent are ranges from $1 \mathrm{hr}$ to 8 hours. $83 \%$ of respondents are spends 1 to 3 hours. A day with social media, followed by $14.3 \%$ are $4-6$ hours and rest $3 \%$ are spent more than 6 hours. It is evident from the table majority of respondents (58) are spending hardly 1-3 hours with social media to satisfy various purposes.

Table.6. Classifications of Respondents Based on Time spent on Traditional Media

\begin{tabular}{|c|c|c|}
\hline $\begin{array}{c}\text { Time Spent } \\
\text { (in hours.) }\end{array}$ & $\begin{array}{c}\text { Number of } \\
\text { respondents }\end{array}$ & Percentage \\
\hline$<1$ & 12 & 17.1 \\
\hline $1-3$ & 46 & 64.3 \\
\hline $4-6$ & 6 & 8.6 \\
\hline$>6$ & 7 & 10 \\
\hline Total & 70 & 100 \\
\hline
\end{tabular}

Source: Primary data

Traditional media also plays a major role in disseminating information among respondents. Though Social media dominating the information market traditional media also have its own space in the mind of customers. Equally the customers (64\%) spend 1-3 hours with tradition media, followed by $17 \%$, less than hour and 10\% more than 6 hours and rest 9\% are spending 4-6 hours with traditional media. The minimum hours of spending is 30 minutes and the maximum was 10 hours. Whereas the minimum hours. Spent with social media begin with 1 hour and the maximum was 8 hours.It is clears from the information that customers are admired with technological advancements.

Table.7. Classifications of Respondents based on Receiving Suggestion before Shopping through Online

\begin{tabular}{|c|c|c|}
\hline $\begin{array}{c}\text { Sources of } \\
\text { Suggestion }\end{array}$ & $\begin{array}{c}\text { Number of } \\
\text { respondents }\end{array}$ & Percentage \\
\hline Family & 3 & 4.3 \\
\hline Friends & 21 & 30.0 \\
\hline No One & 2 & 2.9 \\
\hline User Review & 9 & 12.9 \\
\hline
\end{tabular}




\begin{tabular}{|c|c|c|}
\hline $\begin{array}{c}\text { Family, User } \\
\text { Review }\end{array}$ & 1 & 1.4 \\
\hline Friends, Family & 10 & 14.3 \\
\hline $\begin{array}{c}\text { Friends, User } \\
\text { Review }\end{array}$ & 18 & 25.7 \\
\hline $\begin{array}{c}\text { Friends, Family, } \\
\text { User Review }\end{array}$ & 6 & 8.6 \\
\hline Total & 70 & 100 \\
\hline
\end{tabular}

Source: Primary Data

Gone for the days of physical shopping, where the customer had more confidence to buy products from shops because they could walk in to view items before purchase. Well that day are long gone. Not only are people consistently buying from stores that began online with no physical shop to walk into but they are finding that they have a better variety and more flexibility to shop products. This online shopping makes the customers to visit store in each home, every town in every country on every continent. Now customers have a facility to buy products globally too. Even then the respondents are collecting suggestion from different sources to buy products through online. Of the 70 respondents $30 \%$ of them are asking suggestions from friends, followed by $26 \%$ from friends, user reviews, $14 \%$ are both friends and family, $11 \%$ are reading user reviews, the sources of $9 \%$ were friends, family and user reviews, like rest $4.3 \%-1.4 \%$ and $1.4 \%$ are asking their family, family and user reviews, $3 \%$ are not depend on their suggestion sources instead they took their own decision to buy products without any suggestions.

Table.8. Classifications of Respondents based on often Accessing Social Media Sites

\begin{tabular}{|c|c|c|}
\hline Social Media Sites & $\begin{array}{c}\text { Number of } \\
\text { respondents }\end{array}$ & Percentage \\
\hline Facebook & 34 & 48.6 \\
\hline Instagram & 1 & 1.4 \\
\hline WhatsApp & 3 & 4.3 \\
\hline LinkedIn & 3 & 4.3 \\
\hline Facebook, Instagram & 10 & 14.3 \\
\hline Facebook, LinkedIn & 6 & 8.6 \\
\hline Facebook, Twitter & 4 & 5.7 \\
\hline Facebook, Vero & 1 & 1.4 \\
\hline Facebook, WhatsApp & 1 & 1.4 \\
\hline Instagram, Hike & 1 & 1.4 \\
\hline WhatsApp, Hike & 1 & 1.4 \\
\hline $\begin{array}{c}\text { Facebook, Twitter, } \\
\text { LinkedIn }\end{array}$ & 1 & 1.4 \\
\hline $\begin{array}{c}\text { Twitter, LinkedIn, } \\
\text { Instagram }\end{array}$ & 1 & 1.4 \\
\hline $\begin{array}{c}\text { Facebook, Twitter, } \\
\text { LinkedIn }\end{array}$ & 3 & 4.3 \\
\hline Total & 70 & 100 \\
\hline
\end{tabular}

Source: Primary Data
The Table. 8 exhibits the classifications of respondents based on often accessing social media sites by the users. Out of 70 respondents $48.6 \%$ are often accessing only Facebook, $8.6 \%$ are accessing WhatsApp, LinkedIn each 4.3\%, 1.4\% accessing Instagram, $14.3 \%$ are accessing Facebook and Instagram, 8.6\% are accessing Facebook and LinkedIn, 5.7\% are accessing Facebook and twitter, 4.3\% accessing Facebook, Twitter, LinkedIn, Instagram and the rest Facebook, Vero, Facebook and WhatsApp, Instagram and hike, WhatsApp and Hike, Facebook, twitter and LinkedIn, Twitter, LinkedIn, Instagram each $1.4 \%$. It clearly evident that most of the respondents are accessing Facebook more than any other social media sites.

Table.9. Classifications of Respondents based on the number of Brands following in Social Media

\begin{tabular}{|c|c|c|}
\hline $\begin{array}{c}\text { Number } \\
\text { of brands }\end{array}$ & $\begin{array}{c}\text { Number of } \\
\text { respondents }\end{array}$ & Percentage \\
\hline 1 & 17 & 24.3 \\
\hline 2 & 18 & 25.7 \\
\hline 3 & 5 & 7.1 \\
\hline above 3 & 30 & 42.9 \\
\hline Total & 70 & 100.0 \\
\hline
\end{tabular}

Source: Primary data

The Table. 9 exhibits the number of brands followed by respondents in social media. Their numbers are ranging from 1 to more than 3 . Nearly half of the respondents (43\%) are following more than 3 brands in social media, $26 \%$ of respondents are following two brands, $24 \%$ are only one and only $7 \%$ are following 3 brands.

Table.10. Responses of Respondents while following new Brands in Social Media page

\begin{tabular}{|c|c|c|}
\hline $\begin{array}{c}\text { Respondents while } \\
\text { following brands }\end{array}$ & $\begin{array}{c}\text { Number of } \\
\text { respondents }\end{array}$ & Percentage \\
\hline $\begin{array}{c}\text { Discussing } \\
\text { products/service with } \\
\text { other followers }\end{array}$ & 10 & 14.3 \\
\hline $\begin{array}{c}\text { Search More Info of } \\
\text { Products }\end{array}$ & 31 & 44.3 \\
\hline $\begin{array}{c}\text { Find the related } \\
\text { products }\end{array}$ & 25 & 35.7 \\
\hline Offers And Promotions & 4 & 5.7 \\
\hline Total & 70 & 100.0 \\
\hline
\end{tabular}

Source: Primary Data

Reactions of respondents while following brands in social media page are presented in Table.10. Out of 70 respondents $44.3 \%$ of respondents search more information of the followed brands. $36 \%$ are searching info on the same and related products, $14 \%$ are discussing about the products with other followers of the brands in social media and rest $6 \%$ are searching the products has any promotions or offer sale. It clears that $80 \%$ of the respondents are searching more information on the same and related products. 
Table.11.Knowledge Sources of Products Brands other than Social Media

\begin{tabular}{|c|c|c|}
\hline Particulars & $\begin{array}{c}\text { Number of } \\
\text { respondents }\end{array}$ & Percentage \\
\hline Television & 47 & 67.1 \\
\hline Newspaper & 16 & 22.9 \\
\hline Internet surfing & 5 & 7.1 \\
\hline Friends & 2 & 2.9 \\
\hline Total & 70 & 100.0 \\
\hline
\end{tabular}

Source: Primary Data

Knowledge sources of new product brands other than social media are presented in Table. $11.67 \%$ of respondents are coming to know about brands through Television, $23 \%$ respondents sources were newspaper followed by $7 \%$ internet surfing and $3 \%$ are through friends on face to face chatting. $90 \%$ respondents' sources of product brands were Television and Newspaper.

Table.12. Number of Products Purchased from Social Media through Advertisement

\begin{tabular}{|c|c|c|}
\hline $\begin{array}{c}\text { Products } \\
\text { Purchased }\end{array}$ & $\begin{array}{c}\text { Number of } \\
\text { respondents }\end{array}$ & Percentage \\
\hline 1 & 31 & 44.3 \\
\hline 2 & 13 & 18.6 \\
\hline 3 & 5 & 7.1 \\
\hline above 3 & 21 & 30.0 \\
\hline Total & 70 & 100.0 \\
\hline
\end{tabular}

Source: Primary Data

The Table.12 depicts the number of products purchased through advertisement in social media. The number of products range from 1 to more than 3 . Of the 70 respondents' $44 \%$ are purchased a product from social media advertisement. $30 \%$ were bought more than 3 products, $19 \%$ purchased 2 products and $7 \%$ bought 3 products from social media. Social media advertisements are distributed to the users based on information gathered from target group profiles. Popular Social Media sites Facebook, twitter and so on. Offer different ways of advertise brands. For e.g. Facebook gives options such as promoted posts, sponsored stories, page post ads. The types of social media for advertising products are all aimed at different target audiences.

\subsection{SOCIAL MEDIA ADS TRIGGERS TO PURCHASE A PRODUCT/SERVICE}

Social media advertisements trigger the users to purchase a product/service. It is evident from these information that $54 \%$ of respondents said it triggers them to purchase and the rest $46 \%$ said it's not triggering the mind of users to buy but it induces to click on ads to know more information about product.

\subsection{RESPONSES OF RESPONDENTS ABOUT PRE- JUDGEMENT BEFORE BUYING}

Responses of respondents about pre-judgement before buying shows that out of 70 respondents $36 \%$ said that sometimes they have pre-judgement before buys $29 \%$ reported always they have pre-judgement about the product, $20 \%$ often had, $10 \%$ rarely and $6 \%$ never had a pre-judgement about products.

Table.13. Classifications of Respondents Based on the Products Generally Purchased through Online

\begin{tabular}{|c|c|c|}
\hline Products Purchased & $\begin{array}{c}\text { Number of } \\
\text { respondents }\end{array}$ & Percentage \\
\hline Books & 2 & 3 \\
\hline Electronics & 35 & 49.8 \\
\hline Cosmetics & 2 & 3 \\
\hline $\begin{array}{c}\text { Clothes, PC and Mobile } \\
\text { Accessories }\end{array}$ & 7 & 10.0 \\
\hline Electronics, Kitchen Utensils & 2 & 3 \\
\hline Furniture, Kitchen Utensils & 2 & 3 \\
\hline $\begin{array}{c}\text { Clothes, PC and Mobile } \\
\text { Accessories, Kitchen Utensils }\end{array}$ & 3 & 4 \\
\hline $\begin{array}{c}\text { Electronics, Clothes, PC and } \\
\text { Mobile Accessories }\end{array}$ & 15 & 21.4 \\
\hline $\begin{array}{c}\text { Electronics, Clothes, PC and } \\
\text { Mobile Accessories, Kitchen } \\
\text { Utensils }\end{array}$ & 2 & 3 \\
\hline Total & 70 & 100 \\
\hline
\end{tabular}

Source: Primary Data

The Table.13 have list of products generally purchased by the respondents through online out of 70 respondents $50 \%$ of respondents bought only electronic items such as pc and mobile accessories. 21\% purchased Electronics, Clothes PC and Mobile Accessories, $10 \%$ bought clothes, PC and Mobile accessories, $4 \%$ purchase Clothes, PC and Mobile accessories and kitchen utensils, rest $15 \%$ spent on different lead such as books, cosmetics, electronics, kitchen utensils, furniture each constitutes $3 \%$ respectively. Electronics, clothes, $\mathrm{PC}$ and Mobile accessories products are purchased in larger number through online.

Table.14. Classifications of Respondents Based on Mode of Payment

\begin{tabular}{|c|c|c|}
\hline $\begin{array}{c}\text { Mode of } \\
\text { Payment }\end{array}$ & $\begin{array}{c}\text { Number of } \\
\text { respondents }\end{array}$ & Percentage \\
\hline $\begin{array}{c}\text { Cash on } \\
\text { delivery }\end{array}$ & 34 & 49 \\
\hline $\begin{array}{c}\text { Credit/Debit } \\
\text { card }\end{array}$ & 29 & 41 \\
\hline Net banking & 7 & 10 \\
\hline Total & 70 & 100.0 \\
\hline
\end{tabular}

Source: Primary data

The Table.14 depicts classifications of respondents based on Mode of Payment. Each and every respondents (100\%) purchases variety of products through online. Of those $49 \%$ of respondents preferred COD, followed by $41 \%$ credit/debit card payment rest $10 \%$ choose net banking as mode of payment for purchase. 
Table.15. Classification of Respondents based on Technological Factors influencing to buy products through online

\begin{tabular}{|c|c|c|}
\hline $\begin{array}{c}\text { Technological } \\
\text { Factors }\end{array}$ & $\begin{array}{c}\text { Number of } \\
\text { respondents }\end{array}$ & Percentage \\
\hline $\begin{array}{c}\text { Confident user of } \\
\text { latest IT techniques }\end{array}$ & 15 & 21.4 \\
\hline $\begin{array}{c}\text { For being an advanced } \\
\text { user }\end{array}$ & 20 & 28.6 \\
\hline $\begin{array}{c}\text { Using it as a tool for } \\
\text { knowledge } \\
\text { exploration }\end{array}$ & 35 & 50.0 \\
\hline Total & 70 & 100.0 \\
\hline
\end{tabular}

Source: Primary data

The Table.15 presents technological factors influencing respondents to buy products through online. Out of 70 respondents $50 \%$ reported that they are using social media as a tool for knowledge exploration, $28.6 \%$ said for being an advanced user, and $21.4 \%$ said for confident user of latest IT techniques.

Table.16. Classifications of Respondents Based on Products Purchased in the last month through online

\begin{tabular}{|c|c|c|}
\hline Products Purchased & $\begin{array}{c}\text { Number of } \\
\text { respondents }\end{array}$ & Percentage \\
\hline $\begin{array}{c}\text { Mobile accessories, foot } \\
\text { wear, dresses, books, } \\
\text { Watches }\end{array}$ & 12 & 17.1 \\
\hline Mobile accessories & 11 & 15.7 \\
\hline Not purchased & 7 & 10 \\
\hline Mobile phones & 8 & 11.5 \\
\hline pc accessories & 7 & 10 \\
\hline Electronics & 6 & 8.6 \\
\hline Bags & 4 & 5.7 \\
\hline Watches & 4 & 5.7 \\
\hline Books and Stationeries & 4 & 5.7 \\
\hline $\begin{array}{c}\text { Kids products, Toys, } \\
\text { Perfumes, Leather Belt }\end{array}$ & 4 & 5.7 \\
\hline House hold items & 2 & 3 \\
\hline Adriano board and \\
sensors
\end{tabular}

Source: Primary data

The Table.16 expresses the classification of respondents based on products purchased in the last month through online. Out of 70 respondents $17 \%$ bought mobile accessories, foot wear, dresses, books, watches followed by $16 \%$ mobile accessories, $12 \%$ purchased only mobile phones, $10 \%$ bought pc accessories, another $10 \%$ bought nothing, $8.6 \%$ electronics, 1 Adriano board and sensors, $3 \%$ house hold items, and the rest of bags, watches, books and accessories, kids products, toys, cosmetics, leather belt each $5.7 \%$.
Table.17. Classifications of Respondents Based on Amount Spent in the Last 3 Months through Online

\begin{tabular}{|c|c|c|}
\hline $\begin{array}{c}\text { Particulars } \\
\text { (in Rs) }\end{array}$ & $\begin{array}{c}\text { Number of } \\
\text { respondents }\end{array}$ & Percentage \\
\hline $\begin{array}{c}\text { Amount Not } \\
\text { Spent }\end{array}$ & 8 & 11.4 \\
\hline$<1000$ & 17 & 24.3 \\
\hline $1001-2000$ & 13 & 18.6 \\
\hline $2001-3000$ & 8 & 11.5 \\
\hline $3001-4000$ & 1 & 1.4 \\
\hline $4001-5000$ & 7 & 10 \\
\hline$>5000$ & 16 & 23 \\
\hline Total & 70 & 100 \\
\hline
\end{tabular}

Source: Primary data

The Table.17 shows the classification of respondents based on amount spent in the last 3 months through online. Of the 70 respondents $24.3 \%$ are spent less than Rs. 1000 on online, $18.6 \%$ are spent Rs. 1001-2000 on online, $11.5 \%$ are spent Rs. 20013000 on online, $1.4 \%$ are spent Rs.3001-4000 on online, $10 \%$ are spent Rs.4001-5000 on online, $23 \%$ are spent more than Rs.5000 and rest $11.4 \%$ not spent any amount in the last 3 months. The maximum amount spent by customer was Rs. 45000 .

Table.18. Perception of Respondents about the Importance of Social Media on Product Purchase

\begin{tabular}{|c|c|}
\hline Importance of Social Media on Product Purchase & $\begin{array}{c}\text { Mean } \\
\text { Score }\end{array}$ \\
\hline $\begin{array}{c}\text { Social media has provided more effective platforms to } \\
\text { new products/ service/ brands to draw consumers } \\
\text { attention than mass media channels }\end{array}$ & 3.7 \\
\hline Searching is easier in Social Media than Mass Media & 3.7 \\
\hline $\begin{array}{c}\text { Respondents are satisfied with the information from } \\
\text { Social Media about products }\end{array}$ & 3.7 \\
\hline
\end{tabular}

Source: Primary data

The Table.18 explains the perception of respondents about the Importance of Social Media on Product Purchase. Three statements were used to assess the importance of social media in purchasing. The mean score of those three statements are 3.7 which are very close to the measurement scale of Agree. Hence the respondents agree that Social Media has provided more effective platforms to new products/ service/ brands, also felt searching is easier in social media than mass media and as well they are satisfied with the provided information in social media.

\subsection{RESPONSES OF POST PURCHASE BEHAVIOUR OF THE RESPONDENTS}

All the activities and experiences that follow purchase are included in the post purchase behaviour. Usually after making a purchase, consumer's experiences post-purchase dissonance. They sometimes regret their decisions made. It mainly occurs due to a large number of alternatives or attractiveness of alternatives, and so on. The post-purchase behaviour are assessed under five heads they are Usefulness of Product, Repeat Purchase. 
Recommendation of products to others, Social Media Cause to New Brand Switch and Access the same site after Purchase. For the first statement out of 70 respondents $53 \%$ and $27 \%(80 \%)$ of the respondents felt the usefulness of product purchase through online was very good and good respectively. Regarding to repeat the product purchased $81.4 \%$ reported they repeat purchase in the same site and rest are not. The third statement of post purchase assessment was recommendation of products to others. Most of them $(86 \%)$ stated to recommend others the remaining $(14 \%)$ was not. Social media cause to new brand switch was the fourth statement of post-purchase behaviour $66 \%$ said social media leads to new brand switching whereas $34 \%$ informed it does not caused brand switching. $86 \%$ informed that they access the same site after purchase and the rest $14 \%$ are not. A high level of post-purchase harmony is positively related to the level of satisfaction which the consumer draws out of product usage. From the Table.18 it's understood that customers are satisfied with the post purchase of products as well the social media sites access to purchase.

Table.19. Test Statistics

\begin{tabular}{|c|c|c|c|c|c|}
\hline & Age & Gender & Income & Occupation & $\begin{array}{c}\text { Type of } \\
\text { product }\end{array}$ \\
\hline Chi-Square & $36.200^{\mathrm{a}}$ & $2.800^{\mathrm{b}}$ & $59.286^{\mathrm{c}}$ & $116.857^{\mathrm{d}}$ & $143.429^{\mathrm{e}}$ \\
\hline $\mathrm{df}$ & 2 & 1 & 4 & 5 & 9 \\
\hline $\begin{array}{c}\text { Asymp. } \\
\text { Sig. }\end{array}$ & .000 & .094 & .000 & .000 & .000 \\
\hline
\end{tabular}

\subsubsection{Age Group:}

Ho: There is no significant difference among the Age groups

$\mathbf{H}_{1}$ : There is significant difference among the Age groups

$\chi^{2}: 36.200$

DOF: (3-1)2

Asymp. Sig: 0.000

$\chi^{2}$ calc $<\chi 2$ tab $=$ Accept $\mathrm{H} 0$

$\chi^{2}$ calc $>\chi^{2}$ tab $=$ Reject $\mathrm{H} 0$ and Accept $\mathrm{H}_{1}$

\section{Interpretation:}

- The Significant ( $\mathrm{p}$ value) is 0.000 which is less than stipulated value of 0.05 .

- So this $\chi^{2}$ test conducted is statistically significant. As number of age groups are 3, the DOF is (3-1)2.

- The $\chi^{2}$ calculated values is 36.200

- For 2 degrees of freedom and $\alpha=0.05$, the $\chi^{2}$ table value is 5.991

- Now the calculated $\chi^{2}$ value (36.200) is higher than the table value (5.991).

- Hence Reject $\mathrm{H}_{0}$ and accept $\mathrm{H}_{1}$. This infers that there is a significant difference among the three age groups.

\subsubsection{Gender Group:}

$\mathbf{H}_{0}$ : There is no significant difference among the Gender group

H1: There is significant difference among the Gender group

$\chi^{2}: 2.800$

DOF: (2-1)1

Asymp. Sig: 0.094 $\chi^{2}$ calc $<\chi^{2}$ tab $=$ Accept $\mathrm{H}_{0}$

$\chi^{2}$ calc $>\chi^{2}$ tab $=$ Reject $\mathrm{H}_{0}$ and Accept $\mathrm{H}_{1}$

\section{Interpretation:}

- The Significant (p value) is 0.094 which is greater than stipulated value of 0.05

- So this $\chi^{2}$ test conducted is statistically significant. As number of gender groups are 2, the DOF is (2-1)1.

- The $\chi^{2}$ calculated values is 2.800

- For 1 degrees of freedom and $\alpha=0.05$, the $\chi^{2}$ table value is 3.841

- Now the calculated $\chi^{2}$ value (2.800) is lesser than the table value (3.841).

- Hence Accept $\mathrm{H}_{0}$ and reject $\mathrm{H}_{1}$. This infers that there is no significant difference among the 2 gender groups.

\subsubsection{Income Group:}

$\mathbf{H}_{0}$ : There is no significant difference among the income group

$\mathbf{H}_{1}$ : There is significant difference among the income group

$\chi^{2}: 59.286$

DOF - (5-1)4

Asymp.Sig:0.000

$\chi^{2}$ calc $<\chi^{2}$ tab $=$ Accept $\mathrm{H}_{0}$

$\chi^{2}$ calc $>\chi^{2}$ tab $=$ Reject $\mathrm{H}_{0}$ and Accept $\mathrm{H}_{1}$

\section{Interpretation:}

- The Significant ( $\mathrm{p}$ value) is 0.000 which is less than stipulated value of 0.05 .

- So this $\chi^{2}$ test conducted is statistically significant. As number of income groups are 5, the DOF is (5-1)4.

- The $\chi^{2}$ calculated values is 59.286

- For 4 degrees of freedom and $\alpha=0.05$, the $\chi^{2}$ table value is 9.488

- Now the calculated $\chi^{2}$ value (59.286) is higher than the tale value (9.488).

- Hence Reject $\mathrm{H}_{0}$ and accept $\mathrm{H}_{1}$. This infers that there is a significant difference among the 5 income groups.

\subsubsection{Occupation Group:}

Ho: There is no significant difference among the occupation group

$\mathbf{H}_{1}$ : There is significant difference among the occupation group

$\chi^{2}: 116.857$

DOF- (6-1)5

Asymp.Sig:0.000

$\chi^{2}$ calc $<\chi^{2}$ tab $=$ Accept $\mathrm{H}_{0}$

$\chi^{2}$ calc $>\chi^{2}$ tab $=$ Reject $\mathrm{H}_{0}$ and Accept $\mathrm{H}_{1}$

\section{Interpretation:}

- The Significant ( $\mathrm{p}$ value) is 0.000 which is less than stipulated value of 0.05 .

- So this $\chi^{2}$ test conducted is statistically significant. As Number of occupation groups are 5, the DOF is (6-1)5. 
- The $\chi^{2}$ calculated values is 116.857

- For 5 degrees of freedom and $\alpha=0.05$, the $\chi^{2}$ table value is 11.070

- Now the calculated $\chi^{2}$ value $(116.857)$ is higher than the table value (11.070).

- Hence reject $\mathrm{H}_{0}$ and accept $\mathrm{H}_{1}$. This infers that there is a significant difference among the 6 occupation groups.

Table.20. Distribution of Respondents Based on the Products Purchased and Age

\begin{tabular}{|c|c|c|c|c|}
\hline \multirow{2}{*}{$\begin{array}{c}\text { Number of } \\
\text { Products Purchased }\end{array}$} & \multicolumn{3}{|c|}{ Age } & \multirow{2}{*}{ Total } \\
\cline { 2 - 5 } & $\mathbf{1 8 - 2 2}$ & $\mathbf{2 3 - 2 7}$ & $\mathbf{2 8 - 3 2}$ & \\
\hline 1 & 20 & 4 & 7 & 31 \\
\hline 2 & 9 & 2 & 2 & 13 \\
\hline 3 & 5 & 0 & 0 & 5 \\
\hline$>3$ & 13 & 4 & 4 & 21 \\
\hline Total & 47 & 10 & 13 & 70 \\
\hline
\end{tabular}

Source: Primary Data

It is evident that of the 70 respondents 47 of the respondents are around the age group of 18-22, 10 of the respondents are around the age group of 23-27, 13 of the respondents are around the age group of 28-32. It shows that age group of 18-22 are more willing to buy the products through online.

Table.21. Distribution of Respondents Based on the Products Purchased and Gender

\begin{tabular}{|c|c|c|c|}
\hline \multirow{2}{*}{$\begin{array}{c}\text { Number of Products } \\
\text { Purchased }\end{array}$} & \multicolumn{2}{|c|}{ Gender } & \multirow{2}{*}{ Total } \\
\cline { 2 - 4 } & Male & Female & \\
\hline 1 & 22 & 9 & 31 \\
\hline 2 & 8 & 5 & 13 \\
\hline 3 & 1 & 4 & 5 \\
\hline$>3$ & 11 & 10 & 21 \\
\hline Total & 42 & 28 & 70 \\
\hline
\end{tabular}

Source: Primary Data

It is evident that of the 70 respondents 31 of the respondents bought 1 product, 13 of the respondents bought 2 products, 5 of the respondents bought 3 products per month, 21 respondents bought more than 3 products. Maximum no of products are purchased by men (42) and minimum no of products are purchased by women (28). It shows that Men's are more willing to buy the products through online rather women.

Table.22. Distribution of Respondents Based on the Products Purchased and Amount Spent Online

\begin{tabular}{|c|c|c|c|c|c|c|c|c|}
\hline \multirow[b]{2}{*}{$\begin{array}{l}\text { Number of } \\
\text { Products } \\
\text { Purchased }\end{array}$} & \multicolumn{7}{|c|}{ Amount Spent (in Rs) } & \multirow[b]{2}{*}{ Total } \\
\hline & $<1000$ & $\begin{array}{l}1001- \\
2000\end{array}$ & 2001- & $\begin{array}{l}3001- \\
4000\end{array}$ & $\begin{array}{c}4001- \\
5000\end{array}$ & $>5000$ & $\begin{array}{c}\text { Amount } \\
\text { not } \\
\text { spent }\end{array}$ & \\
\hline 1 & 9 & 6 & 2 & 0 & 1 & 6 & 7 & 31 \\
\hline 2 & 4 & 1 & 1 & 1 & 1 & 4 & 1 & 13 \\
\hline 3 & 2 & 1 & 1 & 0 & 1 & 0 & 0 & 5 \\
\hline
\end{tabular}

\begin{tabular}{|c|c|c|c|c|c|c|c|c|}
\hline$>3$ & 5 & 3 & 2 & 1 & 4 & 6 & 0 & 21 \\
\hline Total & 20 & 11 & 6 & 2 & 7 & 16 & 8 & 70 \\
\hline
\end{tabular}

Source: Primary Data

Out of 70 respondents 20 respondents are spent less than Rs.1000 on online, 11 are spent Rs.1001-2000 on online, 6 are spent Rs.2001-3000 on online, 2 are spent Rs.3001-4000 on online, 7 are spent Rs.4001-5000 on online, 16 are spent more than Rs.5000 and rest 8 respondents are not spent any amount in the last 3 months. The maximum amount spent by customer was Rs. 45000 .

Table.23. Distribution of Respondents Based on the Products Purchased and Mode of Payment

\begin{tabular}{|c|c|c|c|c|}
\hline \multirow{2}{*}{$\begin{array}{c}\text { Number of } \\
\text { Products } \\
\text { Purchased }\end{array}$} & \multicolumn{3}{|c|}{ Mode of Payment } & \multirow{2}{*}{ Total } \\
\cline { 2 - 5 } & $\begin{array}{c}\text { Cash on } \\
\text { delivery }\end{array}$ & $\begin{array}{c}\text { Debit/Credit } \\
\text { Card }\end{array}$ & $\begin{array}{c}\text { Net } \\
\text { banking }\end{array}$ & \\
\hline 1 Product & 15 & 12 & 4 & 31 \\
\hline 2 Products & 6 & 6 & 1 & 13 \\
\hline 3 Products & 4 & 1 & 0 & 5 \\
\hline More than 3 & 9 & 10 & 2 & 21 \\
\hline Total & 34 & 29 & 7 & 70 \\
\hline
\end{tabular}

Source: Primary Data

It is evident that of the 70 respondents 34 of the respondents are choosing Cash on Delivery payment, 29 of the respondents are choosing Debit/Credit card payment and the rest of 7 respondents are only choosing Net banking. It clearly shows that the maximum numbers of respondents who are willing to buy the products through online are choosing cash on delivery mode of payment.

\section{MAJOR FINDINGS}

- Most of the products are purchased by 18-22 years.

- Male are purchasing higher no. of products through online than female.

- Majority of the respondents monthly earning ranges from Rs.20,000-Rs.30,000 pm

- Facebook is dominating the social media sites than other.

- Majority (61.4\%) of the respondents are accessing the social media sites every day.

- Major purpose of using the social media is entertainments and to know information about new products in the market.

- Majority of respondents are spending 1-3 hours in Social Media.

- The customers are spending 8 hours in traditional media.

- Most of the respondents are gather suggestions for purchasing from their friends.

- Often accessed social media site is Facebook

- Nearly half of the respondents are following more than three brands in social media.

- $80 \%$ of the respondents are searching more information on the same and related products 
- Other than social media $90 \%$ of respondents' sources of product brands were Television and Newspaper.

- Nearly half of the respondents are purchasing one product through social media advertisements.

- More than half of the respondents are said social media triggers them to purchase a product/service.

- Only $6 \%$ of the respondents reported that they don't have any pre-judgment about the product before buys.

- Most of the respondents are prefer to buy the products through physical only.

- Electronics, clothes, PC and Mobile accessories are purchased in larger number through online.

- $49 \%$ preferred Cash on Delivery option to buy the products.

- Half of the respondents reported that they are using social media as a tool for knowledge exploration.

- The most purchased products through online are mobile and pc accessories.

- The maximum amount of money spent by customer for online purchase during the last three months was Rs.45,000

- $80 \%$ of the respondents felt the usefulness of product purchase through online was very good.

- Majority of the respondents ready to recommend others to buy the products.

- Most of them reported that they repeat purchase in the same site and rest are not.

- $86 \%$ informed that they access the same site after purchase.

\section{SUGGESTIONS}

- To prevent of the fake websites by filtering the unwanted and irrelevant advertisement using firewall security.

- Social media can keep the privacy of the customers according to their searching of products.

- E-commerce websites can give more offers and discounts to the users who subscribed to their page in social media.

- Make the customers realize how trustworthy their products are through social media.

\section{CONCLUSIONS}

Social networks have a role in influencing the behaviour of consumers in the virtual environments, particularly when the degree of exposure of messages and the relation created between the variety of information given of information given and the customer who is about to make a purchase. There are many people who are still preferred to buy through physical mediums. But also we could find that this major chunk of population belongs to the age group of 18-32 are the potential buyers of certain products such as electronics, clothes, books, home appliances are purchased through online. While coming to the most important attribute that makes a consumer choose to buy products through online are quality, security of credit/debit cards, and variety of products and so on. As per the research consumers usually spend more than three hours a day on the social media and the major purpose was found out to be social networking and information gathering. Consumers rely upon more than one medium in order to enhance their brand related knowledge. It means that they use the combination of various sources for making final purchase decision. Along with the traditional sources, they heavily rely on modern marketing tool i.e. online advertising. Consumers do require detailed information about the brand so as to evaluate its strengths and weaknesses; this ample amount of information saves their time by allowing them to make the purchase decision quickly.

\section{REFERENCES}

[1] J. Scott Armstrong, Vicki G. Morwitzb and V. Kumar, "Sales Forecasts for Existing Consumer Products and Services: Do Purchase Intentions Contribute to Accuracy?", International Journal of Forecasting, Vol. 16, No. 3, pp. 383-397, 2000.

[2] Elisabeta Ioanas and Ivona Stoica, "Social Media and Its Impact on Consumers Behavior", International Journal of Economic Practices and Theories, Vol. 4, No. 2, pp. 295303, 2014.

[3] Gary L. Geissler and George M. Zinkhan, "Consumer Perceptions of the World Wide Web: an Exploratory Study using Focus Group Interviews", Advances in Consumer Research, Vol. 25, pp. 386-392, 1998.

[4] D. Hoffman and T. Novak, "Marketing in Hypermedia Computer-Mediated Environments: Conceptual Foundations", Journal of Marketing, Vol. 60, No. 3, pp. 5068, 1996.

[5] Social Media Marketing India Trends Study, Available at: http://www.ey.com/in/en/services/advisory/ey-socialmedia-marketing-india-trends-study-2016.

[6] Social Media in India, Available at: http://www.livemint.com/Politics/FqcL24fK5aQ68qC6Kzo hJO/Social-media-in-India.html.

[7] Global Social Media Research Summary 2017, Available at: http://www.smartinsights.com/social-mediamarketing/social-media-strategy/new-global-social-mediaresearch/.

[8] E-commerce and Online Shopping in India-Statistics and Facts, Available at: https://www.statista.com/topics/2454/ecommerce-in-india/.

[9] The Latest Numbers on Web, Mobile, and Social Media in India (Infographic), Available at: https://www.techinasia.com/india-web-mobile-data-series2016

[10] Andreas M. Kaplan and Michael Heinlein, "Collaborative Projects (Social Media Application): About Wikipedia, the Free Encyclopedia", Business Horizons, Vol. 57, No. 5, pp. 617-626, 2014.

[11] Mazzini Muda, Rohani Mohd and Salwana Hassan, "Online Purchase Behavior of Generation Y in Malaysia", Procedia Economics and Finance, Vol. 37, pp. 292-298, 2016.

[12] Versha Mehta and Vinod Kumar, "Online Buying Behavior of Customers: A Case Study of Northern India”, Pranjana, Vol. 15, No. 1, pp. 71-88, 2012.

[13] The Wall Street, Available at: http://online.wsj.com/ news/articles/SB100014241278873240633045785231121 93480212, Accessed on 2012. 
[14] Norazah Mohd Suki and Norbayah Mohd Suki, (2016) Examination of Mobile Social Networking Service (SNS) Users' Loyalty: A Structural Approach", International Journal of Social Ecology and Sustainable Development, Vol. 7, No. 3, pp. 57-70, 2016.

[15] Renuka Sharma, Kiran Metha and Shashank Sharma, "Understanding Online Shopping Behaviour of Indian Shoppers", International Journal of Management and Business Studies, Vol. 4, No. 3, pp. 9-18, 2014.
[16] Yulihasri, Md. Aminul Islam and $\mathrm{Ku}$ Amir $\mathrm{Ku}$ Daud, "Factors that Influence Customers' buying Intention on Shopping Online", International Journal of Marketing Studies, Vol. 3, No. 1, pp. 128-139, 2011.

[17] Zivile Bauboniene and Gintare Guleviciute, "E-Commerce Factors Influencing Consumers Online Shopping Decision", Social Technologies, Vol. 5, No. 1, pp. 74-81, 2015. 